\author{
MARJAN MARKOVIKJ \\ Универзитет "Св. Кирил и Методиј” \\ Скопје, Македонија
}

\title{
Семантичка деривација на прасловенскиот глаголски корен *met- во македонскиот јазик
}

Процесите на семантичката деривација претставуваат еден од најзначајните процеси кои го отсликуваат системскиот пренос на информации од семантичкиот континуум во лексиконот на јазикот. Значајно е и дека преку процесите на семантичка деривација може да се набљудува и историскиот развој на семантичките компоненти вградени во лексичките единици.

Семантичката деривација го отсликува системскиот карактер и континуитет на јазичната еволуција при што прототипните семантички компоненти претставуваат нераскинлива врска во текот на формалниот развој на лексичкиот фонд. Овој став ќе го поткрепиме потпирајќи се на антропоцентрично-спацијална теорија за јазикот, односно ќе се обидеме да ги верификуваме поставките дека низ процесите на семантичка деривација може да се набљудуваат асоцијативните низи кои често водат потекло од основните човекови дејства, состојби и движења. Тие асоцијативни низи ги задржуваат основните семантичките компоненти пренесувајќи се од човекот, просторот, времето што го претставуваат реалниот свет, па сѐ до мисловното, апстрактното, метајазичното, претставувајќ́ го менталниот свет.

Од досегашните анализи во рамките на семантичката деривација на одбрани прасловенски глаголски корени произлегува дека токму поимите кои се однесуваат на најосновните човекови положби и движења поседуваат најголема моќ за пренос на основните семантички компоненти од реалниот кон менталниот свет.

Од тие глаголски корени што се однесуваат на основните човекови положби и движења, би можеле да ги издвоиме и: стои, седи, лежи, оди, паѓa, стапнува, мава, фрла, мете/мота/мати, држи, влече, тегне, гребе, дере, бере/бира... 
Таа група глаголски корени и нивните деривати се многу податни за анализа во рамките на процесите на семантичката деривација при што хронолошки може да се набљудува преминот од тие основни човекови положби и движења и неговиот однос кон просторот. Сиот тој процес на семантичка деривација паралелно се одвива и во менталниот свет на човекот и тоа по пат на асоцијации и метафори од реалниот свет. Но секако и реалниот и менталниот свет на човекот се всушност дел од неговата концептуализација која се обидува да ја изрази на најверен начин токму преку јазикот.

Во овој текст се анализира семантичката деривација на прасловенскиот глаголски корен *met- кој е еден од оние глаголски корени коишто ги о3начуваат основните човекови состојби/положби и движења. Во овој случај се работи за изведените основни глаголски форми мете, мота, мати, а во текстот ќе се задржиме на процесите на семантичка деривација на основниот превоен степен - *met-.

Основната (есенцијална) семантичка компонента содржана во прасловенскиот глаголски корен *met- би можеле да ја опишеме како 'движење на раката во сите правци'.

Уште во прасловенскиот период се издвоиле компонентите: 'фрла, врти, се движи брзо'. Во истиот период покрај овие семантички компоненти се развиле и значењата поврзани со природата (меќава) и човековиот дом (мете) 'чисти куќа'

Овој концепт ни овозможува да следиме како таа прототипна семантичка компонента во текот на човековиот (и јазичниот) развој ги шири своите семантички полиња и тоа токму по предвидениот пат: човек - простор -животински/растителен свет - општествен свет.

На тој начин, прототипната семантичка компонента 'движење на раката на човекот (во сите правци)' би можеле да ја разложиме на:

1. 'се движи (брзо)'

а) движење на предмет

б) движење на природните сили

в) движење во сите правци

\section{2. 'фрла'}

3. 'става'

Како што спомнавме погоре, многу рано се развиле компонентите поврзани со чистење на човековиот дом. Следниве деривати ни го потврдуваат тоа:

\section{1. а) движење на предмет \\ мете}

Чисти со метла.

Жената го метеше дворот.

\section{измете - изметува}

Станарите од зградата го изметоа снегот од тротоарите. 


\section{смете - сметува}

Го смете ѓубрето.

замете - заметува

Таа набрзина го замете дворот.

\section{промете - прометува}

Мете набрзина како било.

Го промете дворот и влезе в куќи.

\section{метла}

1. Направа од поврзани стебла на некои растенија со куса или со долга рачка, што служи за метење.

2. Полско растение од кое се прави тој предмет.

Латински: Sorghum vulgare

\section{смет}

Отпадоци што загадуваат нешто.

Го исфрлија сметот на улица.

Канта за смет.

Стар е и дериватот меќава во кој е вградена компонентата на брзо движење:

\section{1. б) движење на природните сили меќава}

Силно невреме, ветер со снег.

Не се плашеше ни од мраз ни од меќава.

\section{ветромет}

1. Место изложено на силен ветар.

Купил колипка на ветрометина па ја претворил во куќичка од соништа.

2. Место изложено на опасности.

Балканот отсекогаш бил ветромет на разни движења.

Како што спомнавме погоре, во текот на човековата и јазична еволуција асоцијативни врски ја шират својата мрежа кон општествениот свет на човекот проследени со паралелен развој на концептуализираниот апстрактен/ ментален свет:

\section{1. в) движење во сите правци}

\section{метеж}

Мешаница, неред, немир, смут

На плоштадот настана голем метеж.

\section{промет}


1. Процес на промена на вредности; размена на стока во пари и обратно; движење на стока и пари.

Примери:

Пред новогодишните празници се прави најголемиот промет.

Прометот се зголеми овој месец.

Фирмата пушти во промет нови производи.

2. движење, раздвиженост

На тоа место нема промет, подзатскриено е.

\section{Семантичка компонента 'фрла’ (како резултат на брзо движење)}

И семантичката компонента 'фрла (како резултат на брзо движење)' е вградена во бројни деривати во македонскиот јазик. Вреди да се спомене дека кај глаголските деривати има и една формална разлика во однос на дериватите од глаголот мете. Имено се работи за перфективниот формант -н- кај глаг. форма метне со што таа станува продуктивно јадро за префиксни и суфиксни глаголски деривации. Оваа појава на образување видски глаголски парови од едно јадро (најчесто перфективно или перфективизитрано) е една од карактеристиките на глаголскиот систем на македонскиот јазик (нес- вед- вез-). Со тоа се редуцираат наследените словенски глаголски деривациски видски модели и се поедноставуваат со потранспарнетни препозитивни и постопозитивни маркери поради мултијазичната и мултикултурна балканска средина.

Глаголски деривати:
метне
заметне - заметнува
изметне - изметнува
одметне - одметнува
наметне - наметнува
пометне-помтнува
преметне - преметнува
сметне - сметнува

\begin{tabular}{|c|c|}
\hline \multicolumn{2}{|c|}{ Глаголски деривати: *met- } \\
\hline мете & метне \\
\hline измете - изметува & изметне - изметнува \\
\hline смете - сметува & сметне - сметнува \\
\hline замете - заметува & заметне - заметнува \\
\hline помете - пометува & пометне - пометнува \\
\hline премете - преметува & преметне -преметнува \\
\hline
\end{tabular}

Slavica Wratislaviensia 165, 2017

(C) for this edition by CNS 
На овој начин, формалната разлика преку формантот -н-, овозможува и семантичката компонента 'фрла' да се задржи во спомнатите деривати.

Следниве примери ни го покажуваат тоа:

\section{метне}

1. фрли

Децата метнаа камен во прозорецот.

2. Пометне, изгуби плод.

Жената го метна бебето.

3. (се метне) Личи на некого, наследи нечија особина.

Си се метнал на мајка ти.

$$
* * *
$$

Т'га за југ

Не, ја не можам овде да седам,

Не, ја не можам мразој да гледам!

Дајте ми крилја ја да си метнам,

И в наши ст'рни да си прелетнам:

На наши места ја да си идам,

Да видам Охрид, Струга да видам.

заметне - заметнува

Зафрли, затури, изгуби нешто.

Тој го заметнал некаде клучот од ковчежето.

\section{изметне - изметнува}

Личи, потсетува на некого, на родител, на близок роднина; се истера.

Целиот се изметна на татка си.

\section{наметне - наметнува}

1. Стави, префрли нешто преку телото без да се облекува.

Примери:

Го наметна палтото и излезе.

Наметна убав, шарен шал.

1 а. Префрли конец, волница, јаже преку нешто оформувајќи гужва, котелец, наметка.

Примери:

Наметна на иглата и следните два котелца ги сплете заедно.

Во апстрактниот/ментален свет:

2. Наложи, спроведе нешто по своја волја.

Примери:

Упорно настојуваше да го наметне своето мислење.

Наметнуваше некои свои проблеми за расправање.

Секогаш успеваше да го наметне својот план за работа. 
3. (се наметне) Се наложи, се постави над другите.

Се наметна со својот директорски авторитет.

одметне - одметнува

1. Со брзо, отсечно движење отфрли, зафрли нешто настрана, наназад.

Примери:

Одеднаш тој се исправи, ја одметна главата наназад и го погледна в очи.

2. (се одметне) Се побуни против власта, законите, поредокот, обично со излегување од местото на живеење заради борба.

Примери:

Напролет тој се одметна в гора.

Неговиот дедо се одметнал и станал војвода.

пометне - пометнува

Прекине бременост; изврши абортус.

Како последица на несреќата девојката пометнала.

преметне - преметнува

1. Фрли нешто преку нешто.

Преметни ја чантата преку столот!

2. Немарно префрли врз нешто.

Го преметна џемперот преку рамо.

3. Преврти, разбуричка, растури нешто.

Децата сѐ ми преметнале низ дома.

4. (се преметне) Скокне, се префрли преку нешто.

Се преметна преку оградата.

\section{Именски деривати со семантичка компонента 'фрла':}

\section{домет}

1. Далечина до која може да се дофрли или да се дофати нешто.

Потерата наближи на домет.

2. Граница на достигнување, остварување во професионална, умствена или друга

Неговите дела се повисок домет во поглед на совршенството.

\section{измет}

1. Несварени состојки од храна што се исфрлаат преку дебелото црево како непотребни, штетни.

Кучешки измет.

\section{намет}

1. Снег навеан од ветрот.

Ги заобиколувавме местата со големи намети. 
2. Тоа што е наметнато, наложено; парична давачка.

Слично со: данок (м.)

\section{наметка}

1. Широка горна облека, без ракави, обично со качулка.

2. Болест на очите што предизвикува слабеење на видот до полно слепило.

3. Едно наметнување конец, волница, јаже, коноп, на нешто оформувајќи нова гужва, јамка и сл.

\section{одмет}

одбивање, отфрлање, исклучување

Не е на одмет - не е за отфрлање

\section{одметник}

Тој што се побунил, што се одметнал.

Одметник од народот.

Дело на одметници.

\section{премет}

Слободен скок од гимнастичка справа.

\section{ракомет}

Игра со топка со рака

\section{пушкомет}

Дострел до каде што може да досегне куршум од пушка.

Тие беа на пушкомет далеку од него.

\section{огномет}

Исфрлање од ракети што се распрскуваат во разнобојна светлина на ноќното небо при прослави или празници.

\section{Новогодишен огномет}

Како што може да се види од наведените примери, семантичката компонента 'фрла' е силно и еднозначно вградена во сите наведени глаголски и именски деривати.

\section{Семантичка компонента 'става'}

Следниве примери се однесуваат на повоопштена семантичка компонента којашто се развила од 'фрла', а тоа е семантичката компонента 'става поставува'. 


\section{вметне - вметнува}

Стави нешто внатре или помеѓу нешто; дополнително внесе.

Примери:

На ова место ќе вметнеме апликации од кожа.

Авторот на студијата вметнал неколку познати цитати.

\section{подметне - подметнува}

1. Стави, кладе нешто под нешто.

Примери:

Болничарката подметна перница под главата на пациентот.

2. Предизвика дејство, најчесто со негативни последици.

Примери:

Подметнале бомба во седиштето на организацијата.

Некој подметнал пожар во зградата.

Тој се служи со разни подметнувања за да дојде до целта.

\section{*подмет / предмет}

*Подмет е според латински subject < subiicere 'фрла/става долу’; од латинскиот гл. iacere 'фрла' ; в. проекција, инјекција...

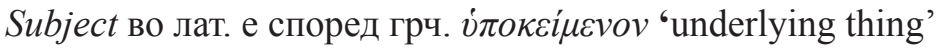

Англиски jet $<$ франц. jet, jeter

\section{Заклучок}

Од анализата на семантичката деривација прасловенскиот глаг. корен *met- неговите деривати произлегуваат повеќе семантички компоненти коишто со текот на времето (по пат на асоцијативни поврзувања) ги ширеле своите семантички полиња во однос на еволуирачката концептуализација на светот пренесена преку јазикот. Така, почнувајќи од основната (прототипна) семантичка компонента ,движење на раката во сите правци', уште во прасловенскиот период се издвоиле компонентите: ,фрла, врти, се движи брзо’ како и компонентата (мете), чисти куќа'.

Низ анализата на семантичките компоненти вградени во дериватите од овој прасловенски глаголски корен може да се согледа дека преку процесите на семантичката деривација, македонскиот јазик покажува две универзални тенденции: континуирање на прасловенските семантички компоненти зачувувајќи некои архаични форми, и една поопшта тенденција која ја верификува антропоцентрично-спацијалната теорија за јазикот, а тоа е дека прототипните човекови состојби, дејства и движења се основата за преносот на семантичките компоненти од материјалниот, човеков реален свет, па сѐ до најапстрактниот - менталниот свет. 


\section{Библиографија}

\section{Литература}

Асенова П., 1989, Балканско Езикознание, София: Издателство наука и изкуство.

Видоески Б., 1998, Дијалектите на македонскиот јазик, t. 1, Скопје: МАНУ.

Конески Бл., 1981, Граматика на македонскиот јазик, Скопје: Култура.

Конески Бл., 1982, Историја на македонскиот јазик, Скопје: Култура.

Конески Бл., 1986, Речник на македонскиот јазик (со српскохрватски толкувања), Скопје: Македонска книга.

Мургоски 3., 2011, Толковен речник на современиот македонски јазик (второ издание), Скопје.

Case, Animacy and Semantic Roles, 2011, red. S. Kittila, K. Vasti, J. Ylikoski, Amsterdam-Philadelphia: John Benjamins Publishing Company.

Encyclopedia of Indo-European Culture, 1997, red. J.P. Mallory, D.Q. Adams, London-Chicago: Fitzroy Dearborn Publishers.

Siatkowski J., 2004, Studia nad wptywami obcymi w ogólnosłowiańskim atlasie językowym, Warszawa: Uniwersytet Warszawski, Instytut Slawistyki Zachodniej i Południowej.

Sławski F., 1974, Słownik prasłowiański I, Warszawa: Zakład Narodowy im. Ossolińskich.

Topolińska Z., 1996, Anthropocentric Language Theory as Organizing Principle of the Slavic Case System, „BPTJ” 52.

Topolińska Z., 2012, The Balkan Sprachbund from a Slavic perspective, Зборник (Матице српске) за филологију и лингвистику LIII/1, Нови Сад, стр. 33-60.

Topolińska Z., Spirala ewolucji. Polski Macedoński 11. Konfrontacja (nie tylko) gramatyczna, Wrocław [w druku].

Topolińska Z., 2014, Anthropocentric Case Theory: How are Humans coded in Doscourse?, „The Kenneth E. Naylor Memorial Lecture Series in South Slavic Linguistics", nr 6, New York: Beech Stave Press.

Wierzbicka A., 1972, Semantic Primitives, Athenäum-Frankfurt/M.: Verlag.

\section{Етимолошки речници}

A Dictionary of Selected Synonyms in the Principal Indo-European Languages, red. C. Darling Buck, Chicago: University Press, 1949, reprinted 1988.

Boryś W., 2005, Stownik etymologiczny języka polskiego, Kraków: Wydawnictwo Literackie.

Bruckner A., 1957, Stownik etymologiczny języka polskiego, Warszawa: Wiedza Powszechna.

Български етимологичен речник, 1971, София: Българска Академия на науките.

Фасмер М., 1986, Зтимологический словарь русккого языка, Москва: Издательство „Прогресс“.

Miklosich F., 1886, Etymologisches Wörterbuch der Slavischen Sprachen, Wien: Wilhelm Braumüller.

Miklosich F., 1865, Lexicon Palaeoslovenico-Graeco-Latinum, Wien: G. Braumüller.

Skok P., 1971, Etimologijski rječnik hrvatskoga ili srpskoga jezika, Zagreb: Skok.

The Oxford Introduction to Proto-Indo-European and the Proto-Indo-European World, 2006, red. J.P. Mallory, D.Q. Adams, New York: Oxford University Press.

\section{Други извори}

Dodder R., Dare R., Complex Adaptive Systems and Complexity Theory, Inter-related Knowledge Domains, http://web.mit.edu/esd.83/www/notebook/ComplexityKD.PDF. 
Steels L., 2000, Language as a complex adaptive system. Parallel problem solving from naturePPSN VI, [w:] Lecture Note in Computer Science, red. M. Schoenauer, Vol. 1917, Berlin: Springer.

\section{Semantic derivation of the protoslavic verbal root *met- in Macedonian language}

\section{Summary}

The subject of analysis in this paper is protoslavic verbal root *met- which formal and semantic development can be traced from a very old period. The research is based on anthropocentric-spatial language theory which helps to analyze how the meaning embedded in some verbal roots representing basic human positions and movements can transfer and rise through evolution of the conceptualization (of the material and mental world). The author analyzes the derivatives of the protoslavic verbal root *met- with embedded semantic components (move in all directions, throw...) and how the formal verbal and nominal derivatives carry this semantic information through language evolution.

Keywords: anthropocentric-spatial language theory, semantic derivation, Macedonian language, semantics, verbal roots

\section{Semantyczne pochodzenie protosłowiańskiego rdzenia werbalnego *met- w języku macedońskim}

\section{Streszczenie}

Przedmiotem analizy jest protosłowiański rdzeń werbalny *met-, którego formalny i semantyczny rozwija się od dawien dawna. Badania opierają się na teorii antropocentryczno-przestrzennej, która pomaga dociec, w jaki sposób, osadzone w niektórych werbalnych korzeniach znaczenie, reprezentuje podstawowe ludzkie stany oraz konceptualizuje świat materialny i umysłowy. Autor analizuje pochodne protosłowiańskiego korzenia werbalnego *met- wraz z wbudowanymi komponentami semantycznymi (ruch we wszystkich kierunkach, czasownik „rzucać”...) oraz sprawdza, jak formalne słowne i nominalne pochodne instrumenty przenoszą tę semantyczną informację poprzez ewolucję językową.

Stowa kluczowe: teoria antropocentryczno-przestrzenna, derywacja semantyczna, język macedoński, semantyka, rdzenie werbalne 